del Río, C.J., \& Martínez, S. (2021). Diversity and biostratigraphy of the late Oligocene-late Miocene sand dollars (Echinoidea: Scutelliformes) of Argentina and Uruguay. Revista de Biología Tropical, 69(S1), 35-50. DOI 10.15517/rbt.v69iSuppl.1.46324

DOI 10.15517/rbt.v69iSuppl.1.46324

\title{
Diversity and biostratigraphy of the late Oligocene-late Miocene sand dollars (Echinoidea: Scutelliformes) of Argentina and Uruguay
}

\author{
Claudia J. del Río ${ }^{1}$ \\ Sergio Martínez ${ }^{2 *}$
}

1. Museo Argentino de Ciencias Naturales-Consejo Nacional de Investigaciones Científicas y Técnicas de Argentina, Buenos Aires, Argentina; claudiajdelrio@gmail.com

2. Facultad de Ciencias, Universidad de la República, Montevideo, Uruguay; smart@fcien.edu.uy (*Correspondence).

\author{
Received 19-V-2020. Corrected 21-VIII-2020. Accepted 07-IX-2020.
}

\begin{abstract}
Introduction: Scutelliforms were diverse and widespread in shallow marine environments during Neogene times in South America. Nevertheless, they have almost never been used as biostratigraphic tools. Objective: To provide a refined stratigraphic frame useful for calibrating temporal dimensions of scutelliform diversity from Argentina and Uruguay and its correlation with the molluscan assemblages previously proposed. Methods: A detailed survey of their geographic and stratigraphic provenance was carried out. We revised both the bibliography and collections (institutional and from our own field work). Results: The group is represented by 14 species belonging to six genera, and four assemblages were identified. Numerical dates of the Neogene marine rocks obtained recently allowed their placement in a chronological scheme: "Iheringiella" sp. A is restricted to the late Oligocene, the genera Camachoaster and "Eoscutella" and the species Monophoraster telfordi to the early Miocene, Abertella gualichensis and Abertella miskellyi to the middle Miocene, and Monophoraster duboisi, Amplaster coloniensis and Amplaster ellipticus to the late Miocene. Non-lunulate scutelliforms are not restricted to the late Oligocene as previously supposed. The oldest occurrence of the genus Monophoraster corresponds to the early Miocene, and along with Iheringiella are long-living taxa that embrace the 25.3 Ma-18.1 Ma (Iheringiella patagonensis) and approximately $15 \mathrm{Ma}-6.48 \mathrm{Ma}$ (Monophoraster darwini) intervals. The presence of Iheringiella in the early Miocene of northeastern Patagonia is corroborated, reaching there its northernmost distribution. Monophoraster darwini has a temporal range from the late Miocene (where it was previously thought to be restricted) back to the middle Miocene, since this is the species yielded in the well-known and discussed "Monophoraster and Venericor Beds". Conclusions: The Paleogene-Neogene scutelliforms of Argentina and Uruguay range from the late Oligocene to the late Miocene. There is a good correspondence among the numerical ages, molluscan biozones and scutelliform assemblages.
\end{abstract}

Key words: Echinoidea; Scutelliformes; sand dollars; Paleogene; Neogene; Argentina; Uruguay.

In the Southwestern Atlantic region, a thick, shallow marine sedimentary sequence characterized by a highly diverse molluscan fauna is exposed, associated with sometimes dense concentrations of scutelliforms. While the molluscs attracted the attention of paleontologists since the 19th century by means of d' Orbigny's (1842) and Darwin's (1839, 1846) publications, echinoids remained largely ignored. It was not until the last few decades that the taxonomic knowledge and the geographic and stratigraphic provenance of southern South American scutelliforms increased and improved, pointing to a diverse and widespread 
group that was abundant in the shallow marine environments during Neogene times.

Echinoids, and particularly scutelliforms, have almost never been used as biostratigraphic tools in South America. The scarce references dealing with this group as stratigraphic tools are those of Ameghino (1898, 1906), Ihering $(1897,1900,1907,1927)$, and Ortmann (1902), who claimed that the "one-holed" genus Monophoraster was restricted to the late Miocene of Patagonia ("Entrerriense strata") and the "non-holed" Iheringiella to the Oligocene ("Patagoniense strata").

Ongoing numerical dating provides a refined stratigraphic frame extremely useful in calibrating the temporal dimensions of scutelline diversity and its correlation with the molluscan assemblages proposed by del Río (1988, 2004). In order to attain this goal, we performed a synthesis of the available information, bringing together the highly dispersed taxonomic bibliography with every stratigraphic and geographic distribution adequately documented. This analysis indicates that scutelliforms are stratigraphically constrained in this region, and that along with the molluscan assemblages, they are useful in the correlation of marine units from different Patagonian basins.

Antecedents: Early collections from eastern Patagonia were made by Charles Darwin during the voyage of the "HMS Beagle" along the Patagonian coast in 1833-1834, and by Carlos Ameghino during his 15 field trips between 1886 and 1903. In the course of the Princeton Expedition (1896-1899) John B. Hatcher made a large collection in the surroundings of Argentino, Pueyrredón, and Posadas lakes in western Patagonia.

Darwin collected sand dollars from the strata later known as San Julián and Puerto Madryn Formations, mentioned as Scutella in his "Journal..." (Darwin, 1839) and "Geological observations..." (Darwin, 1846). Based on Darwin's specimens, Desor (1847) described three nominal species in a brief account, naming them as Monophora darwini, Echinarachnius juliensis, and Scutella patagonensis. Subsequently, Cotteau (1884) added Monophora duboisi from the Paraná Formation, a unit exposed in northeastern Argentina. Lahille (1898) synonymized Desor's E. juliensis and S. patagonensis under a new and monotypic genus: Iheringia (type species: Iheringia patagonensis). Homonymy problems led Berg (1898) and Lambert and Thiéry (1921) to change Iheringia to Iheringiella and Monophora to Monophoraster.

Thereafter, and for many years, scutelliforms from Argentina and Uruguay were believed to be represented by only three species: the one-holed Monophoraster darwini and M. duboisi, and the non-holed Iheringiella patagonensis (e.g. Loriol, 1901; Loriol,1902; Ortmann, 1902; Mortensen, 1948; Bernasconi, 1959; Durham, 1966). The genus Amplaster was added to these by Martínez (1984) to hold the late Miocene Uruguayan species Amplaster coloniensis. Later, the middle Miocene Amplaster alatus Rossi de Garcia and Levy, 1989 and the late Miocene Amplaster ellipticus Mooi, Martínez and Parma, 2000 were also included in this genus. Abertella, a genus that had been thought to be restricted to North America, was discovered in the Argentinean middle Miocene by Martínez, Reichler and Mooi (2005) and later, another new species of this age was described by Kroh, Mooi, del Río and Neumann (2013). Mooi, Martínez and del Río (2016) increased the specific richness of Monophoraster through the inclusion of the new species, Monophoraster telfordi (early Miocene), and Mooi, Martínez, del Río and Ramos (2018) described another nonholed genus from the Neogene of Argentina: Camachoaster.

There remain some controversial species: "Eoscutella" mirandae, which as discussed by Mooi et al. (2018) is not an Eoscutellidae but probably an Abertellidae, and two undescribed taxa that further increase the richness of the group ("Iheringiella" sp. A and "Iheringiella" sp. B).

In total, since the three species were recognized in the early 20th century, the group now includes 14 species distributed in six genera and four families that are endemic to the American continent. 


\section{MATERIALS AND METHODS}

We carried out a bibliographic analysis that retained only those references with adequate descriptions or illustrations concerning South American scutelliforms, and re-examined more than 300 specimens housed in different institutions, including their types when available.

To the previously known classic fossiliferous sites mentioned in the geological literature, we add other new ones (Fig. 1).

The repositories and their acronyms are as follows:

CASG: California Academy of Sciences, Geology collection, San Francisco, USA.

CIRGEO-PI: Centro de Investigaciones en Recursos Geológicos, currently housed at MACN-Pi, Ciudad Autónoma de Buenos Aires, Argentina.

CPBA: Cátedra de Paleontología de la Universidad de Buenos Aires, Ciudad Autónoma de Buenos Aires, Argentina.

FCDP: Departamento de Paleontología, Facultad de Ciencias, Universidad de la República, Montevideo, Uruguay.

MACN-Pi: Colección Paleoinvertebrados, Museo Argentino de Ciencias Naturales Bernardino Rivadavia, Ciudad Autónoma de Buenos Aires, Argentina.

MAS-Pi: Museo de Ciencias Naturales y Antropológicas "Pro. Antonio Serrano", Paraná, Argentina.

MB: Museum für Naturkunde, Berlin, Germany.

MCZ: Museum of Comparative Zoology, Cambridge, Massachusetts, USA.

MNA-CPO: Museo Nacional de Antropología, Colección Paleontológica Oliveras, currently housed at the Museo Nacional de Historia Natural, Montevideo, Uruguay.

PRI: Paleontological Research Institution, Ithaca, USA.

SEGEMAR: Servicio Geológico Minero Argentino, San Martín, Buenos Aires, Argentina.

\section{RESULTS}

Stratigraphic setting of scutelliform beds: The shallow marine late Oligocene-late Miocene sedimentary sequence exposed in Argentina and Uruguay is represented by the San Julián Formation (late Oligocene in the Austral Basin, early Miocene in the Mazarredo Sub-basin), El Chacay, Estancia 25 de Mayo and Monte León Formations (early Miocene, Austral Basin), Chenque Formation (early Miocene-middle Miocene, San Jorge Basin), Gaiman, Bajo del Gualicho, Vaca Mahuida Formations, and the "Isla Escondida Beds" (middle Miocene) and the Puerto Madryn, Río Negro, Paraná and Camacho Formations (late Miocene).

An important framework for the analysis is made up of the late Paleogene-Neogene molluscan assemblages and their relative ages proposed by del Río (1988, 2004). Late Miocene molluscs were gathered in the Aequipecten paranensis Zone (del Río, 1988), and the late Oligocene-middle Miocene ones were separated by del Río (2004) into five informal assemblages known as: 1) Panopea sierrana-Parinomya patagonensis Assemblage (PP) (late Oligocene); three assemblages of early Miocene age: 2) Jorgechlamys centralis-Reticulochlamys borjasensis Assemblage (JR), 3) Reticulochlamys zinsmeisteri-Struthiolarella patagoniensis-Pleuromeris cruzensis Assemblage (RSP), and 4) Pseudoportlandia glabraAntimelatoma quemadensis Assemblage (PA); and the middle Miocene: 5) Nodipecten sp.Venericor abasolensis-Glycymerita camaronesia Assemblage (NVG).

These assemblages were subjected to numerical dating, and the results support their relative ages. As shown in Fig. 2, the PP, PA and RSP Assemblages are restricted to the Eastern sector of the Austral Basin and have not yet been identified in Western Patagonia. The PP Assemblage is recognized in the San 


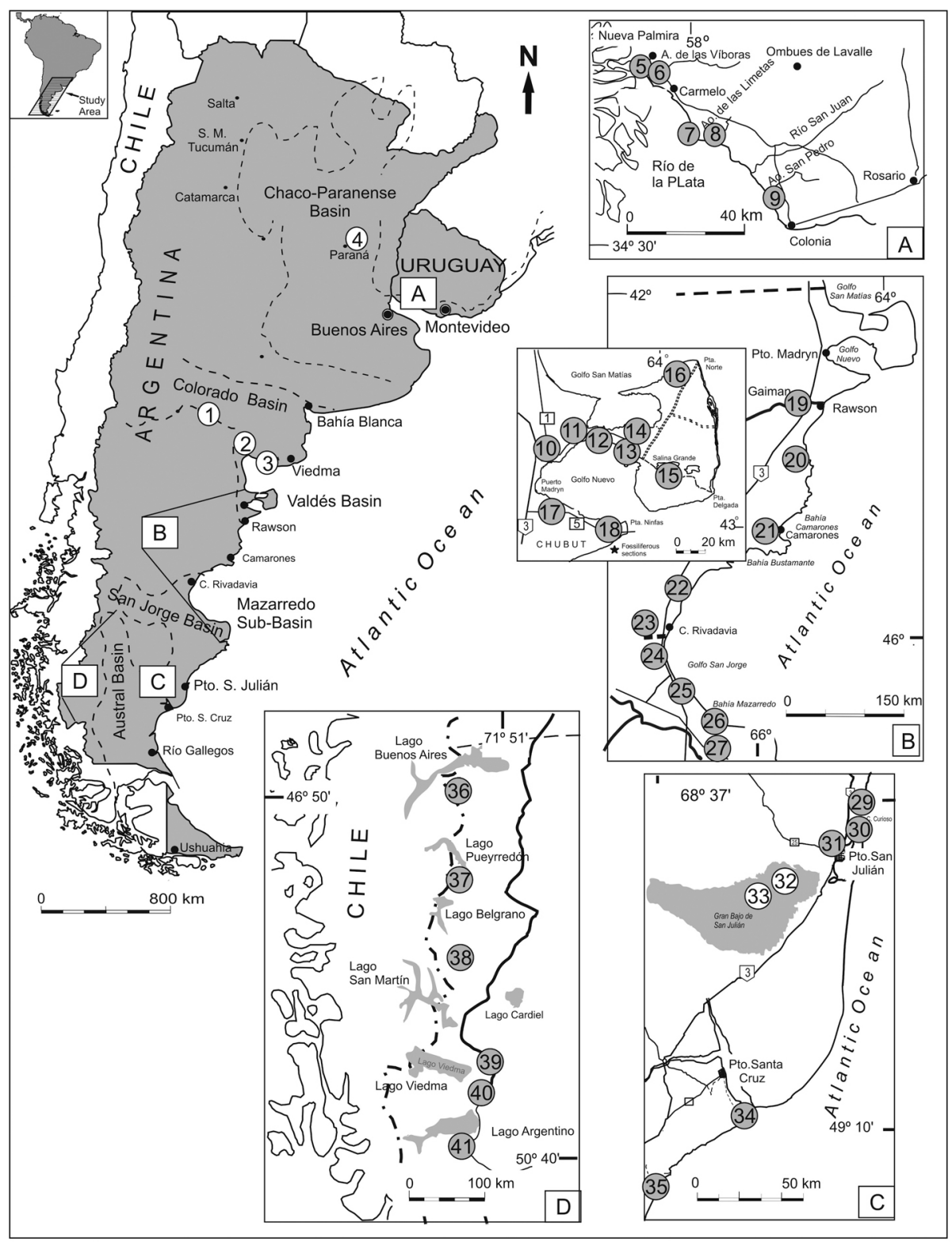

Fig. 1. Late Oligocene-late Miocene localities with scutelliforms in Argentina and Uruguay. 1. Yacimiento La Rinconada; 2. Puesto Astorga; 3. Barranca Final; 4. Paraná-Diamante area; 5. Barranca de los Loros; 6. Cerro Bautista; 7. El Manzano; 8. Arroyo de las Limetas; 9. San Pedro; 10. El Doradillo; 11. Cerro Prismático; 12. Eje Tentativo; 13. Punta Piaggio-Punta Pirámides area; 14. Lote 39; 15. Salina Grande; 16. Estancia San Lorenzo; 17. Cerro Avanzado; 18. Bahía Craker; 19. Trelew; 20. Isla Escondida; 21. surroundings of Camarones; 22. Pico Salamanca; 23. Estancia Busnadiego; 24. Punta Maqueda-Punta Delgada; 25. Punta Casamayor-Cañadón El Lobo; 26. Punta Nava; 27. Cerro Blanco; 28. Estancia Floradora; 29. Playa La Mina; 30. Playa Drake/Punta Cuevas; 31. Oven Point; 32. Cerro Pan de Azúcar; 33. Meseta Chica; 34. Darwin Section; 35. Yegua Quemada-Jack Harvey creeks; 36. Río Zeballos; 37. Río Tarde-Veranada Cárcamo-Laguna Oriental; 38. Shell-Gap; 39. upper Chalía river; 40. Estancia La Laurita; 41. Estancia Quién Sabe. 


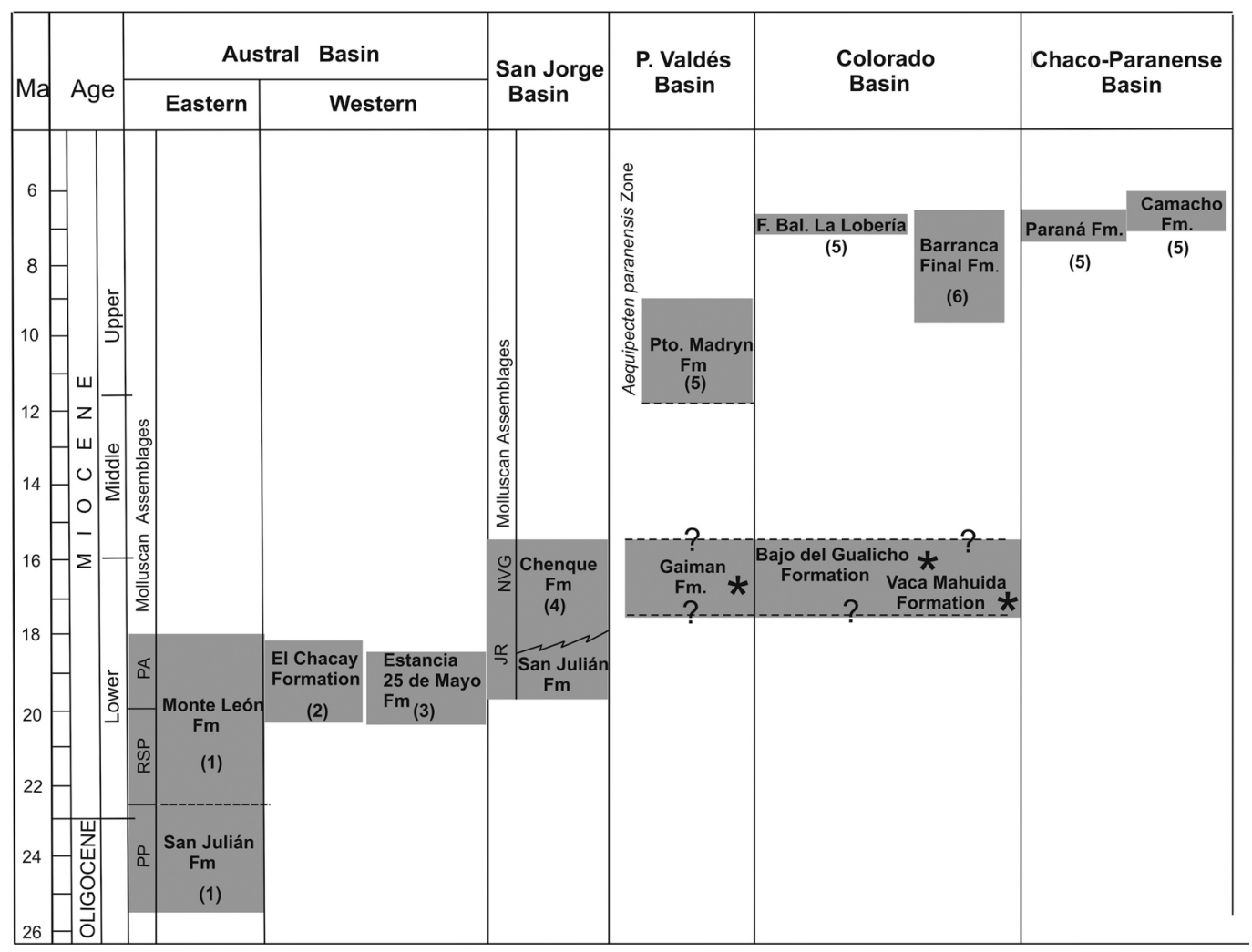

Fig. 2. Chronostratigraphic chart of late Oligocene-late Miocene marine units based on ${ }^{87} \mathrm{Sr} /{ }^{86} \mathrm{Sr}$ data calculated by: 1 . Parras et al. (2012); 2. Cuitiño et al. (2015b); 3. Cuitiño et al. (2012); 4. Cuitiño et al. (2015a); 5. del Río et al. (2018); 6. Palazzesi et al. (2014); (*) no isotopic data available for these units. Abbreviations: PP = Panopea sierrana-Parinomya patagonensis Assemblage; RSP = Reticulochlamys zinsmeisteri-Struthiolarella patagoniensis-Pleuromeris cruzensis Assemblage; $\mathrm{JR}=$ Jorgechlamys centralis-Reticulochlamys borjasensis Assemblage; NVG = Nodipecten $\mathrm{sp}$-Venericor abasolensisGlycymerita camaronesia Assemblage (modified from del Río et al., 2018).

Julián Formation (25.32 Ma-22.7 Ma), and the $\mathrm{PA}$ and RSP ones are restricted to the Monte León Formation (19.36 Ma-17.91 Ma).

The JR Assemblage embraces the early Miocene deposits of the San Julián Formation in the Mazarredo Sub-basin and the basal Parasequences 1 and 2 of the Chenque Formation in the San Jorge Basin (19.69 Ma-15.68 Ma). On the basis of its paleontological content, the JR Assemblage was correlated with the PA and RSP Assemblages by del Río (2004), a correlation later supported by numerical ages obtained by Parras, Dix and Griffin (2012) and Cuitiño, Scasso, Ventura-Santos and Mancini (2015a).

The NVG Assemblage was recognized by del Río (2004) in Parasequence 5 of the
Chenque Formation, and in the Gaiman and Camarones Formations, and in the lower and middle section of the Bajo del Gualicho Formation. There are no numerical ages for these units, but the NVG is considered as of middle Miocene age.

Finally, the Aequipecten paranensis Zone is recognized in the Puerto Madryn, Barranca Final, Río Negro (Facies Balneario La Lobería), Paraná and Camacho Formations that embrace the interval 11.4-6.60 Ma (del Río, Martínez, McArthur, Thirwall, \& Pérez, 2018).

Fig. 1 shows the fossiliferous localities with sand dollars, Figure 2 the lithostratigraphic units mentioned above, Fig. 3 the geographical and temporal distribution of the studied taxa, 


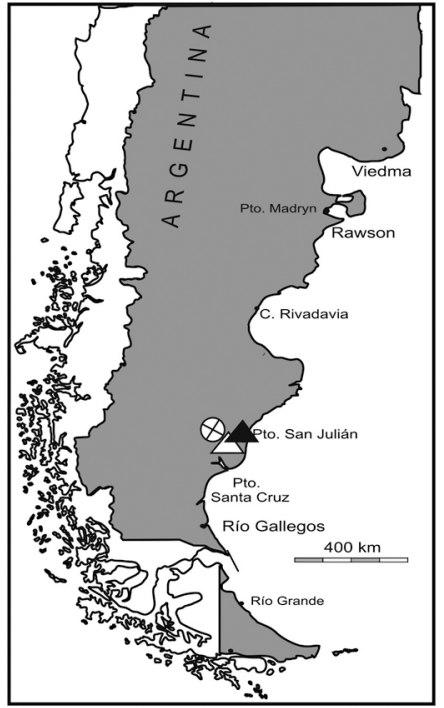

late Oligocene

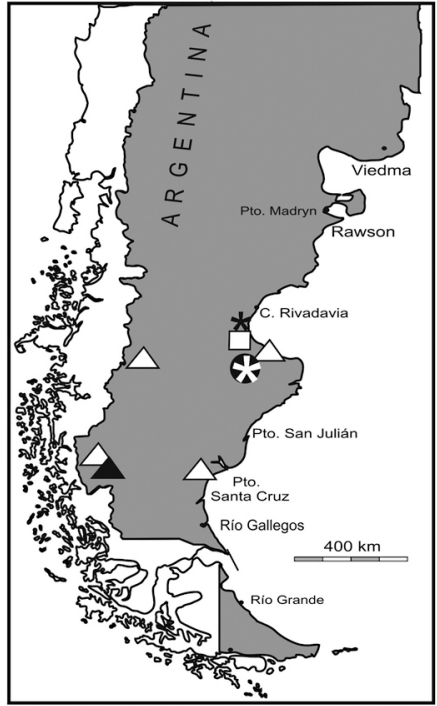

early Miocene

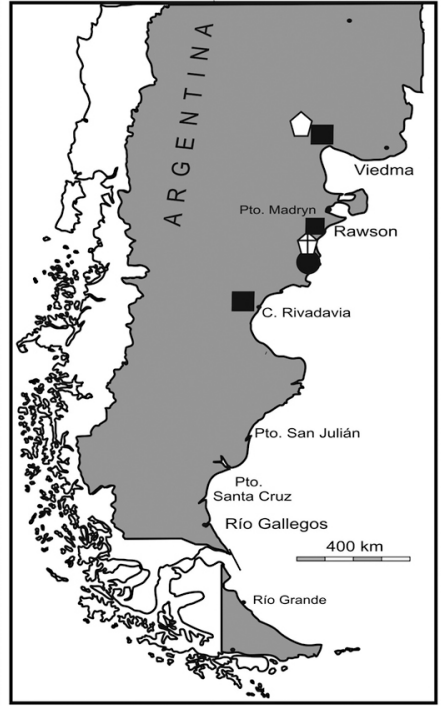

middle Miocene

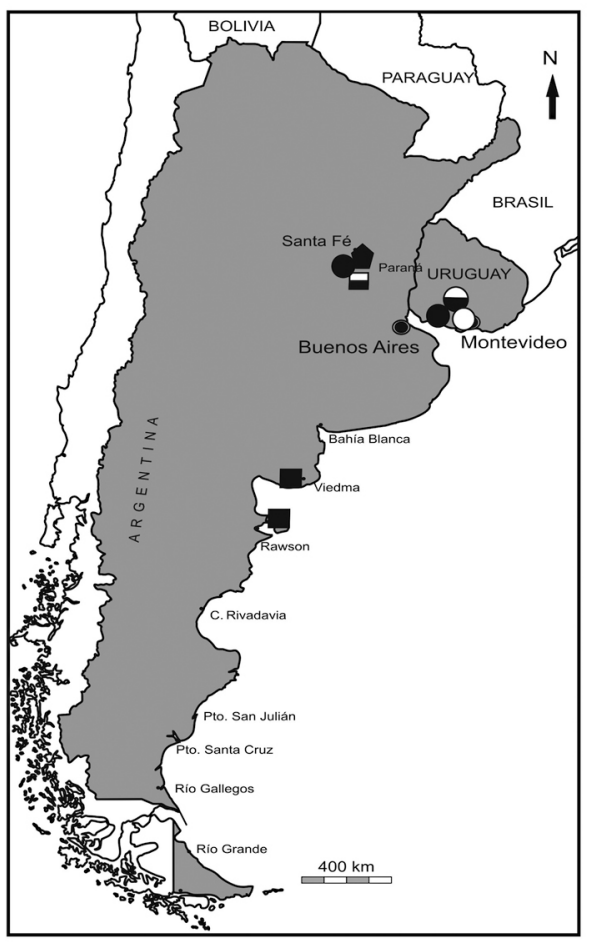

$\triangle$ Iheringiella patagoniensis

"Iheringiella"sp. B

$\bigotimes$ "Iheringiella"sp. A

Camachoaster maquedensis

Eoscutella mirandae

$\square$ Monophoraster telfordi

- Monophoraster darwini

$\square$ Monophoraster duboisi

$\bigcirc$ Abertella gualichensis

Abertella n.sp.

$\bigoplus$ Abertella miskellyi

Amplaster ellipticus

- Amplaster alatus

Amplaster coloniensis

late Miocene

Fig. 3. Temporal and geographic distribution of late Oligocene-late Miocene scutelliforms of Argentina and Uruguay (fossiliferous sites in Fig. 1). 


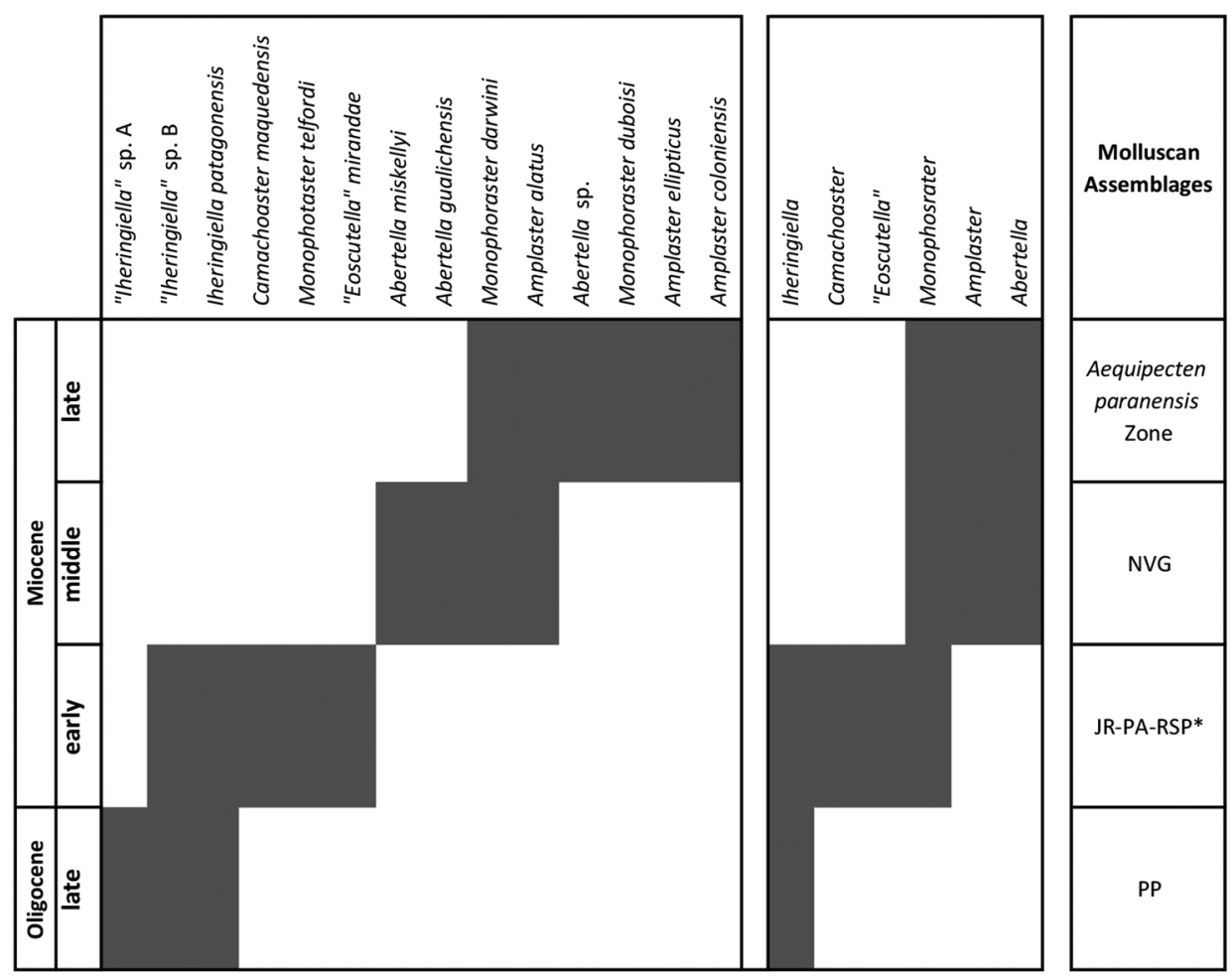

Fig. 4. Correspondence between the temporal range of the studied scutelliforms and that of the molluscan assemblages. Abbreviations in Results.

Fig. 4 the correspondence between molluscan assemblages and scutelliforms. The appendix 1 includes the positively identified materials with their temporal, lithostratigraphic, and geographic locations.

Late Oligocene: Fig. 5. This interval is represented by the San Julián Formation where sand dollars are very frequent found, contained in rocks exposed in two areas near to each other: the Bajo de San Julián (lower Gran Bajo Member), and the surroundings of the San Julián Port (upper Meseta Chica Member). The Gran Bajo Member (Meseta Chica, Pan de Azúcar, Manatial Salado) contains one of the densest concentrations of scutelliforms in Patagonia, represented by Iheringiella patagonensis and by two as yet undescribed new species ("Iheringiella" sp. A and "Iheringiella" sp. B). Dated at 24.40 Ma and 25.32 Ma (late Oligocene) (Parras et al., 2012), these beds record the oldest proven occurrence of scutelliforms in Patagonia, and are constituted by matrix- and bioclast-supported calcareous bioclastic sandstones (facies Gmm of Parras \& Casadío, 2005) deposited below fair-weather wave-base, in lower shoreface to offshore environments. In the Meseta Chica section, sand dollars are exceptionally abundant and found in multi-event deposits where monospecific beds with well-preserved imbricated or chaotically oriented entire tests are intercalated with monospecific, thin horizons of brachiopods, Zygochlamys geminata, or oysters in life position. A similar dense concentration is present in the surroundings of the San Julián Port (Playa La Mina, Oven Point, Playa Drake/Punta Cuevas). In this area, the Meseta Chica Member was dated by Sr- isotope chronostratigraphy at 22.7 Ma to 23.53 Ma (Parras et al., 2012) and is characterized by multi-event, massive, medium, ochreous sandstones that contain in 


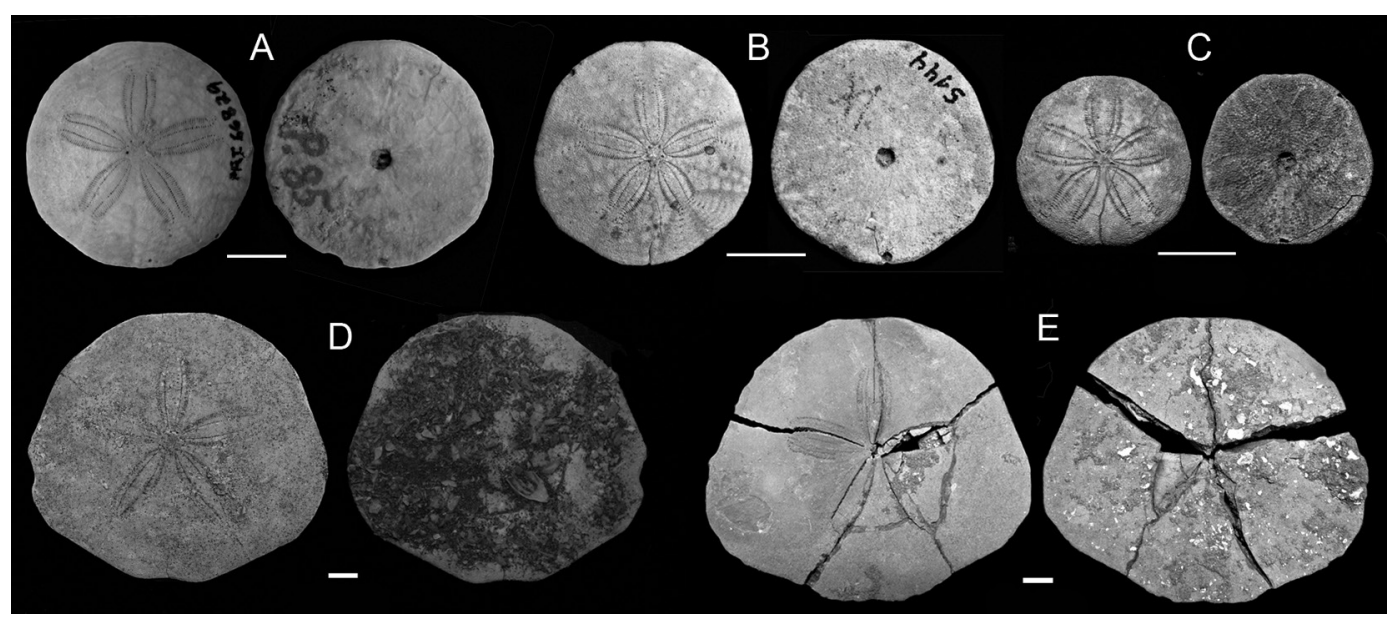

Fig. 5. Representative scutelliforms from the late Oligocene of Argentina, aboral and oral surfaces shown in each pair of figures for a given species. A. Iheringiella patagonensis, PRI 66829, Oven Point. B. Iheringiella patagonensis MACN-Pi 5144, Pan de Azúcar. C. "Iheringiella” sp. A, MACN-Pi w/n, Meseta Chica. D. "Iheringiella” sp. B, MACN-Pi w/n, Meseta Chica. E. "Iheringiella" sp. B, CPBA 20181, Playa La Mina. Scale bar $=10 \mathrm{~mm}$.

situ accumulations of $I$. patagonensis and the undescribed species, "Iheringiella" sp. B.

Early Miocene: Fig. 6. Marine deposits of early Miocene age are widely exposed in the eastern (Monte León Formation) and western (Estancia 25 de Mayo and El Chacay Formations) sectors of the Austral Basin, and in the San Jorge Basin (lower Chenque Formation and San Julián Formation).

In contrast to the San Julián Formation, scutelliforms are not frequent in the Monte León Formation, where they are represented only by $I$. patagonensis recovered from the finely laminated siltstones and sandstones exposed at the Darwin Section, suggesting a subtidal- or even intertidal environment (Parras \& Griffin, 2009), deposited between 19.36 Ma-19.27 Ma ago (Parras et al., 2012). Iheringiella patagonensis is also recorded from the uppermost beds of the unit exposed at Yegua Quemada and Jack Harvey, both localities being correlated with the Las Cuevas section, dated at 17.91 Ma (Parras et al., 2012).

Largely correlated with the San Julián Formation in its type area (southern Austral Basin), the age of the marine rocks exposed in the Mazarredo Sub-basin of Bellosi (1995) (San Jorge Basin) are today recognized as early Miocene (del Río et al., in prep.), and correlated with the Monte León Formation at its type locality (southeastern Austral Basin). Exposures in Punta Casamayor-Cañadón El Lobo-Punta Nava area consist of $40 \mathrm{~m}$ thick yellowish fine to medium sandstones and siltstones capped by calcareous shell-beds, where echinoids are represented by I. patagonensis, Hypechinus patagonensis, Schizaster sp., and Isechinus praecursor, associated with abundant, articulated specimens of the pectinids Zygochlamys jorgensis and Jorgechlamys centralis. The same deposits are exposed at Cerro Blanco where the base of the San Julián Formation is represented by massive yellowish medium sandstones containing "Eoscutella" mirandae followed by highly fossiliferous sandstones containing I. patagonensis associated with Neoinoceramus ameghinoi, J. centralis, J. juliania, and brachiopods (Parma, 1985). The I. patagonensis reference from Cerro Blanco was not included in our database because the material was not illustrated and there are no specimens in the collections. This record is considered unconfirmed herein. 


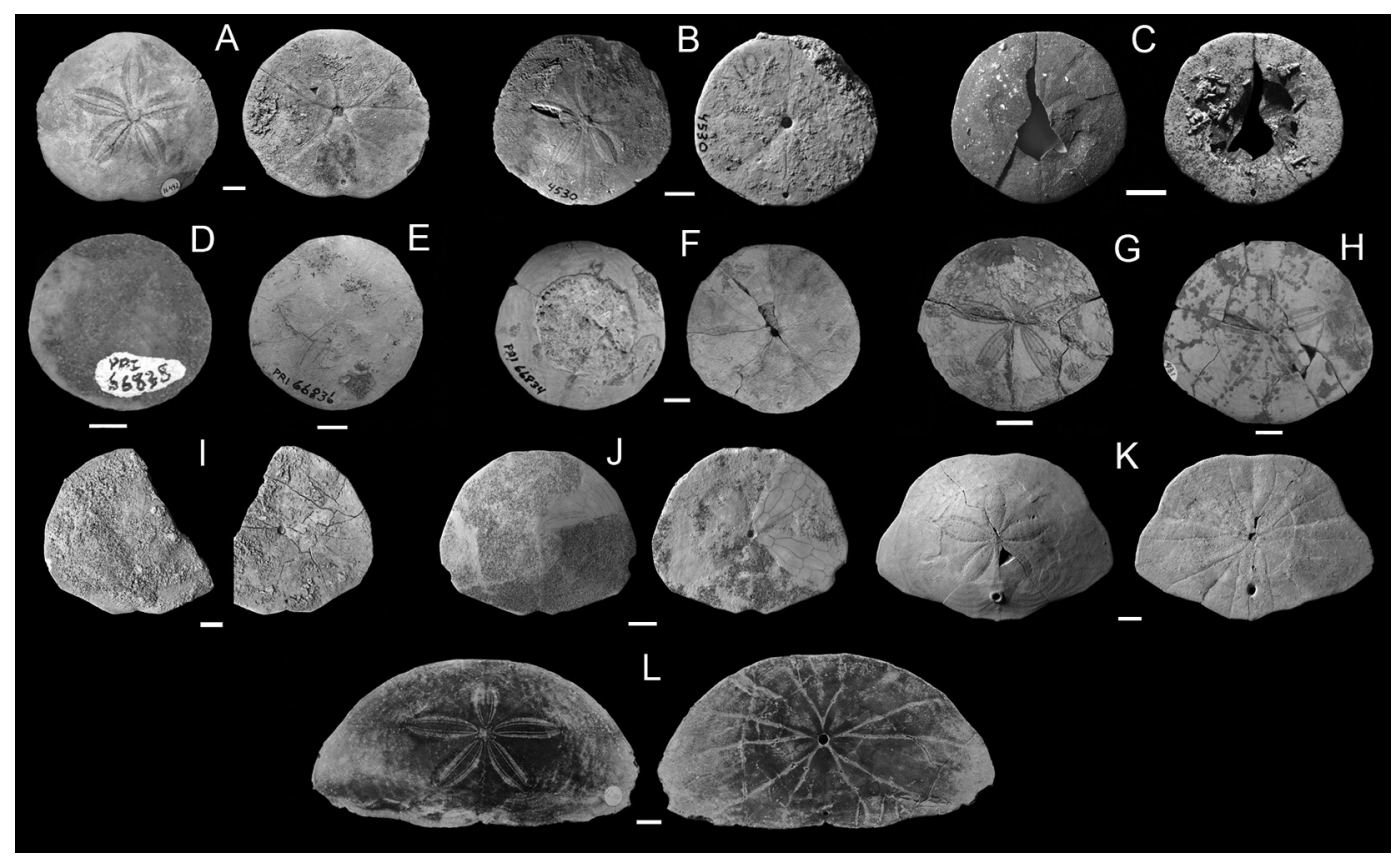

Fig. 6. Representative scutelliforms from the early Miocene of Argentina, aboral and oral surfaces shown in each pair of figures for a given species. A-G. Iheringiella patagonensis. A. CPBA 16492, Punta Lobo. B. PRI 4530, Punta Nava. C. MACN 4547, Yegua Quemada. D. PRI 66838, Pueyrredón Lake. E. PRI 66836, Shell-Gap. F. PRI 66834, Río Chalía. G. PRI 83920, Estancia La Laurita. H. “Iheringiella” sp. B, PRI 83635, Estancia La Laurita. I. "Iheringiella” sp. B, MACN-Pi w/n, Estancia Floradora. J. Camachoaster maquedensis MACN-PI 5809 (Holotype), Punta Maqueda (modified from Mooi et al., 2018). K. Monophoraster telfordi, MACN-PI 5807 (Holotype), Punta Maqueda (modified from Mooi et al., 2016). L. "Eoscutella" mirandae, CPBA 12901 (Holotype), Cerro Blanco. Scale bar $=10 \mathrm{~mm}$.

The Chenque Formation is composed of a $500 \mathrm{~m}$ thick marine sedimentary sequence exposed in the surroundings of Punta Maqueda (Parasequence 2 of Bellosi, 1995) northwards to the Comodoro Rivadavia region (Parasequences 1-5). Its lowermost strata (Parasequences 1 and 2) were dated by Sr-isotope chronostratigraphy by Cuitiño et al. (2015a) to between 19.69 Ma-15.68 Ma (early Miocenebasal middle Miocene). The Chenque Formation exposed at Punta Maqueda is represented by a $12 \mathrm{~m}$ thick intercalation of grayish fine sandstones with ochreous and greenish, moderately fossiliferous sandstones, deposited in a distal lower shoreface environment at the base, to a middle shoreface environment at the top of the section. One thin bed, up to 15 $\mathrm{cm}$ thick and composed of very fine-grained sandstones, contains one of the most diverse assemblages of echinoderms in the Neogene of Argentina and Uruguay. These are represented by patches of asteroids (Astropecten sp.), the ophiuroid Ophiocrossota kollembergorium, the spatangoid Brisaster iheringi, the non-lunulate scutelliform Camachoaster maquedensis, and the lunulate Monophoraster telfordi. These taxa are recorded in thin, autochthonous assemblages in life position, deposited in distalmiddle shoreface environments, dominated by a low hydraulic energy regime and affected by sporadic, weak storms. Laterally associated is a less diverse but abundant fauna, mainly made up of census assemblages of the bivalves Atrina magellanica and Crassostrea hatcheri in life position, and thin, chaotically oriented accumulations of the pectinids Swiftopecten iheringi, Z. jorgensis, Pixiechlamys quemadensis, and the gastropod Trophon santacruzensis. 
The Estancia 25 de Mayo and El Chacay Formations are exposed in the Western Austral Basin. The former unit crops out in the Lago Argentino area and was dated by Cuitiño et al. (2012), who proposed an ${ }^{87} \mathrm{Sr} /{ }^{86} \mathrm{Sr}$ age ranging between 20 to $19 \mathrm{Ma}$. Sand dollars are rare and recorded in the lowermost beds of the Quien Sabe Member (Estancia Quien Sabe, Estancia La Laurita), which is composed of shell beds and highly bioturbated sandstones deposited in shallow, moderately low energy environments (Cuitiño \& Scasso, 2010). The recognized scutelliforms are I. patagonensis and "Iheringiella" sp. B, associated with a poorly preserved and rich molluscan fauna mainly represented by $C$. hatcheri, Panopea nucleus, Panopea panis, undetermined cardids, Austrocallista australis, Ameghinomya argentina, Miomelon petersoni, Valdesia cuevensis, Valdesia dalli, and Perissodonta ameghinoi.

The El Chacay Formation, exposed between the Lago Buenos Aires to the north and the Lago Posadas to the south, was dated by Cuitiño,Ventura-Santos, Muruaga and Scasso (2015b) between 20.3 Ma to18.1 Ma, and scutelliforms are slightly more common and diverse than in the Estancia 25 de Mayo Formation. The assemblages mostly come from the highly bioturbated sandy beds intercalated with bioclastic horizons placed at the lower middle part of the unit (Facies B, lithofacies
Smb of Cuitiño et al., 2015b), deposited in a lower shoreface environment (Cuitiño et al., 2015b). Main fossiliferous exposures are: Río Zeballos, Río Tarde, Veranada Cárcamo, Laguna Oriental and Shell-Gap. Iheringiella patagonensis is associated with the echinoids Platipygus posthumus, Isechinus praecursor and Brisaster sp. (Chiesa, Parma \& Camacho, 1995), and to a rich molluscan fauna represented by $C$. hatcheri, Z. jorgensis, A. argentina, P. nucleus, Valdesia collaris, Perissodonta ameghinoi, Cirsotrema rugulosa, M. petersoni, and Miomelon orbignyana.

Middle Miocene: Fig. 7. Marine beds of this age correspond to the uppermost strata of the Chenque Formation and to other lithostratigraphic units that have not yet been studied in detail: Vaca Mahuida, Bajo del Gualicho, Gaiman, and Camarones Formations, and the Isla Escondida Beds. Except for the Chenque Formation, there are no numerical dates for these units, and in some cases there are still discrepancies about their relative ages. The presence of the NVG molluscan assemblage makes them contemporaneous with the middle Miocene upper beds of the Chenque Formation. Echinoids are not frequent elements but constitute a moderately high diversity group.

The uppermost strata of the Chenque Formation exposed at Estancia Busnadiego

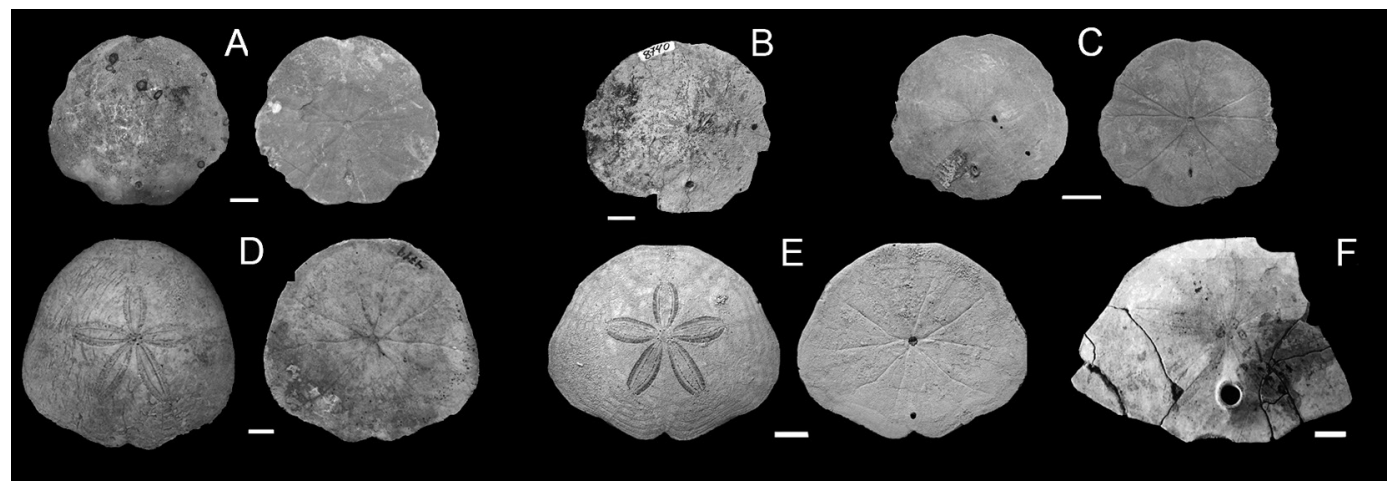

Fig. 7. Representative scutelliforms from the middle Miocene of Argentina, aboral and oral surfaces shown in each pair of figures for a given species except in B and F. A-C. Monophoraster darwini. A. MACN-PI 4580, Estancia Busnadiego. B. CPBA 8740, Pico Salamanca. C. MACN-Pi w/n, Bajo del Gualicho. D. Abertella gualichensis, MACN-PI 4714 (Holotype), Bajo del Gualicho. E. Abertella miskellyi, MB E.7463 (Holotype), near Camarones City (modified from Kroh et al. 2013). F. Amplaster alatus, SEGEMAR 15526 (Paratype), Estancia Isla Escondida. Scale bar $=10 \mathrm{~mm}$. 
and Pico Salamanca (Parasequence 5 of Bellosi, 1995) have been named as "Estratos con Monophoraster y Venericor" by Camacho (1974) and although they have not been numerically dated, are surely younger than the underlying Parasequence 3 (15.37 Ma), and older than the beginning of the deposition of the overlying continental sediments of the Santa Cruz Formation dated to $15 \mathrm{Ma}$ (Cuitiño et al., 2015b), embracing in this way the middle Miocene. These beds are characterized by Monophoraster darwini, associated with the bivalves Neovenericor austroplata, Glycymerita camaronesia, A. argentina, Retotapes striatolamellata, and the gastropods Pachycymbiola ameghinoi, Penion subrecta, Perissodonta iheringii, and Perissodonta ameghinoi, among the commonest species.

Exposures of the Vaca Mahuida Formation have been recorded by Uliana and Camacho (1975) and Concheyro (1988) south of the Colorado River in a narrow strip that stretches from the boundary between the Río Negro, Neuquén and La Pampa provinces eastwards to Lomita Colorada. These beds consist of a $50 \mathrm{~m}$ thick layer of sandstones, mudstones, and massive or cross-stratified limestones, deposited in intertidal and subtidal environments. Uliana and Camacho (1975) found a poorly diversified and scarce marine assemblage at Yacimiento La Rinconda, represented by the molluscs $N$. austroplata and Torcula hautali, and identified a scutelliform as I. patagonensis. Unfortunately, that material is lost, and illustrations provided are not conclusive. Scutelliforms from the Vaca Mahuida Formation housed at the Cátedra de Paleontología (Universidad de Buenos Aires, Argentina) (CPBA 15842-15849) are the only ones available for study, but these specimens were severely encrusted, hampering a proper taxonomic assignment. For these reasons, this material has not been included in the appendix 1.

The Bajo del Gualicho Formation is exposed at Salinas del Gualicho, and its lower and middle sections were correlated by del Río (2004) with the upper part of the Chenque Formation on the basis of the NVG Molluscan
Assemblage. At Puesto Astorga, scutelliforms are found in thin, intercalated monospecific accumulations of $M$. darwini or Abertella gualichensis, floating in massive medium sandstones. Upwards in the section, fragments or entire tests of both species are found together, associated with $N$. austroplata, Nodipecten salis and Pachycymbiola arriolensis.

In the surroundings of Gaiman and Trelew cities, the Gaiman Formation is composed of a $50 \mathrm{~m}$ thick succession of thin coquinas, whitish to yellowish tuffs, tuffaceous sandstones, and tuffaceous mudstones, deposited in a shallow, storm-dominated marine environment. Badly preserved tests of $M$. darwini are recorded in the uppermost shell-beds associated with N. austroplata.

Kroh et al. (2013) described Abertella miskellyi from an old and still unknown fossiliferous locality in the surroundings of Camarones city, where the Camarones Formation is exposed containing the typical NVG Molluscan Assemblage represented by $N$. austroplata, $G$. camaronesia and T. hautali.

There is little agreement among authors in identifying the marine "Isla Escondida beds". The sedimentary succession exposed in this area consists of a $150 \mathrm{~m}$ thick intercalation of whithish, ochreous, and yellowish sediments represented by tuffs, tuffaceous sandstones, tuffaceous mudstones, sandy tuffs, and poorly fossiliferous beds. Rossi de García and Levy (1989) described Amplaster alatus from the upper section, species later discussed by Mooi, Martínez and Parma (2000). Amplaster alatus is associated with $N$. austroplata, G. camaronesia, and $T$. hautali, placing the unit in the middle Miocene.

Late Miocene: Fig. 8. During the late Miocene, a new transgression of the sea, a product of various events spread over a large area from Cabo Buentiempo (southernmost Argentina) northwards to Uruguay. Its deposits have been intensely studied and are recognized as Puerto Madryn, Barranca Final, Río Negro (Facies Balneario La Lobería), Paraná, and Camacho Formations. 


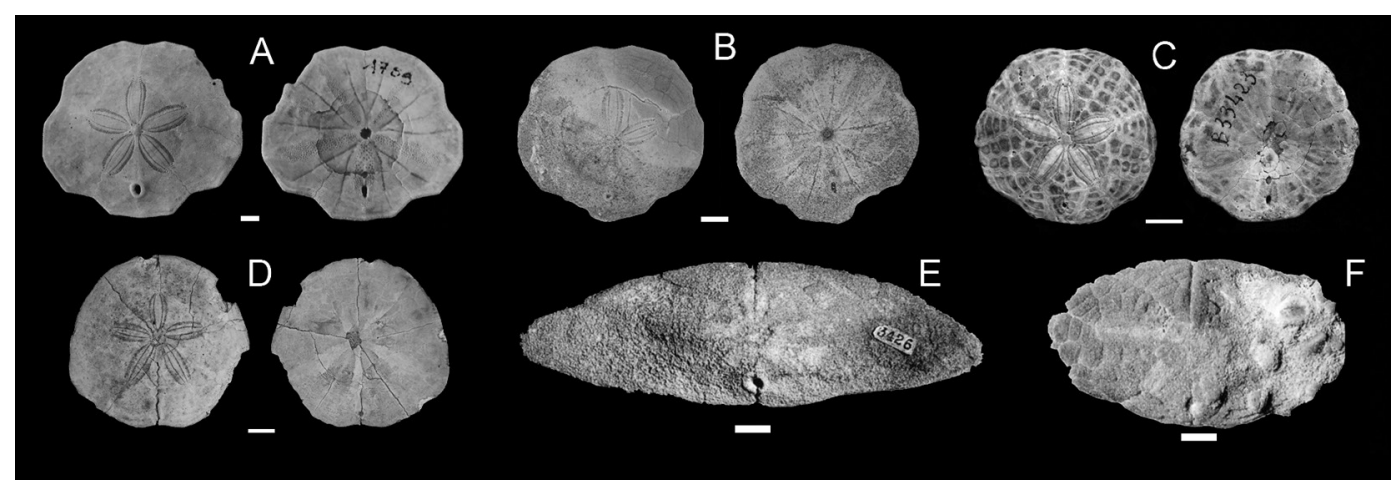

Fig. 8. Representative scutelliforms from the late Miocene of Argentina and Uruguay, aboral and oral surfaces shown in each pair of figures for a given species except in E and F. A. Monophoraster darwini, FCDP 1789, Eje Tentativo. B. Monophoraster darwini (col. Cuitiño thesis w/n), Barranca Final. C. Monophoraster duboisi, MNHN B33423, Paraná. D. Abertella sp., MAS-Pi 511, Paraná. E. Amplaster coloniensis, MNA-CPO 3426 (Holotype), Barranca de los loros. F. Amplaster ellipticus, MNA-CPO 3425 (Paratype), San Pedro. Scale bar $=10 \mathrm{~mm}$.

The Puerto Madryn Formation records one of the most abundant and dense accumulations of scutelliform tests in the Neogene of Patagonia, similar to those observed in the late Oligocene San Julián Formation at Bajo San Julián. The molluscan assemblage belongs to the Aequipecten paranensis Zone (del Río, 1988), recently dated to between 11.4-9.25 Ma (del Río et al., 2018). The only known scutelliform species is $M$. darwini, which is evenly distributed from the base to the top of the unit. Composition and taphonomy of the fossiliferous concentrations have been discussed by del Río, Martínez and Scasso (2001), who described two types of taphonomic accumulations of scutelliforms: the MO Assemblage ( $M$. darwini and oysters) and the OMA Assemblage (oysters, M. darwini, Aequipecten paranensis). The first type is constituted by up to $4 \mathrm{~cm}$ thick census assemblages of entire tests in life position in medium to fine sandstones or in heterolithic beds, deposited in a shallow and very high-energy environment, with strong wave action, in upper shoreface settings situated just seawards of the breaking wave zone. The OMA Assemblage is not as common as the MO Assemblage and is represented by highly fragmented tests that may be part of autochthonous single-event or of allochthonous multievent, time-averaged accumulations that infill large erosive tidal channels of high-energy shoreface environments.

The Barranca Final Formation and the Facies Balneario La Lobería (Río Negro Formation) crop out in the cliffs situated along the northern littoral of San Matías Gulf. The base of the section at Balneario La Lobería consists of $2 \mathrm{~m}$ of barren, ochreous, cross-stratified, medium sandstones, overlain by $7 \mathrm{~m}$ of yellowish, massive, fine sandstones, and yields well preserved $M$. darwini in life position associated with $A$. paranensis, Ostrea sp., and Pododesmus camachoi. These beds have been recently dated to 7.08-6.55 Ma by del Río et al. (2018) using Sr-isotope chronostratigraphy. The Barranca Final Formation, located 117 $\mathrm{km}$ west from Balneario La Lobería, consists of an intercalation of mudstones, very fine sandstones, and thin fossiliferous strata that yield M. darwini, A. paranensis, Moirechlamys actinodes, and oysters. According to Palazzesi et al. (2014), the sediments were deposited in a low-energy shallow marine/estuarine environment, dated in 9.61 Ma (lower section) to 6.48 Ma (middle part of the section).

Numerical values recently obtained by del Río et al. (2018) place the Paraná Formation between 7.55-6.67 Ma. Scutelliforms are scarce, being represented by Monophoraster duboisi, A. alatus (mentioned herein for the 
first time from this unit), and by an undescribed new species of Abertella (Pérez et al., 2011) (Fig. 8D) from Punta Gorda Sur (Diamante), where a $2.5 \mathrm{~m}$ thick intercalation of sandstones and mudstones are capped by a $30 \mathrm{~cm}$ thick amalgamated shell bed that contains Anadara bonplandeana, Crassostrea cf. rhizophorae, A. paranensis, Leopecten oblongus, and Chionopsis munsterii (del Río et al., 2018).

The Camacho Formation (7.20 Ma-6.92 Ma) yields a richer assemblage than the Paraná Formation, represented by M. duboisi, A. alatus, Amplaster ellipticus, and Amplaster coloniensis, contained in shallow, subtidal pelitic and sandy rocks, usually deposited by storms (Martínez, 1994).

\section{DISCUSSION}

Fig. 4 shows the temporal distribution of scutelliforms and its correlation with the molluscan assemblages. No Paleogene-Neogene scutelliforms older than the late Oligocene or younger than the late Miocene have been found or mentioned in the literature for the studied area. The oldest occurrences belong to the abundantly represented Iheringiella patagonensis in the Southern Austral Basin (San Julián Formation, ca $25 \mathrm{Ma}-23 \mathrm{Ma}$ ), associated with the less common "Iheringiella" sp. A and "Iheringiella" sp. B, approximately 25-23 Ma. Iheringiella patagonensis survived until $18 \mathrm{Ma}$ (Monte León, El Chacay and Estancia 25 de Mayo Formations). This species is also recorded in northern Patagonia (San Jorge Basin, Mazarredo Sub-basin), in the San Julián Formation dated to $21 \mathrm{Ma}$ (del Río et al., in prep.), which represents the northernmost occurrence of this species.

Around $18 \mathrm{Ma}$, scutelliforms were widely distributed in Patagonia and represented by the surviving Iheringiella patagonensis and "Iheringiella" sp. B (Austral Basin), along with Camachoaster maquedensis and Monophoraster telfordi (San Jorge Basin), this being the oldest and southernmost known occurrence for the genus Monophoraster. At this point it is important to emphasize that in contrast to previous claims (e.g. Ameghino, 1898; Ameghino,1906; Ihering, 1897; Ihering, 1900; Ihering, 1907; Ihering, 1927; Ortmann, 1902; Teisseire, 1928; Bernasconi, 1959), the non-holed genus Iheringiella was coeval with the one-holed Monophoraster during the early Miocene.

Iheringiella was extinct by the end of the early Miocene, but Monophoraster, Amplaster, and Abertella diversified to make up the characteristic middle Miocene genera of northern Patagonia, surviving into the late Miocene. Monophoraster darwini and I. patagonensis constituted long-living taxa, existing approximately from $15 \mathrm{Ma}$ to $6.48 \mathrm{Ma}$ and $25.3 \mathrm{Ma}$ to18.1 Ma, respectively. This temporal range is longer than that estimated by molecular studies in Recent related scutellines such as Mellita and Encope (Coppard et al., 2013; Coppard, 2016; Coppard and Lessios, 2017), leaving open a question concerning possible existence of cryptic species among the fossil taxa.

Monophoraster darwini and Monophoraster duboisi are the youngest representatives of the Monophoraster lineage, and along with Amplaster coloniensis, Amplaster ellipticus and Amplaster alatus characterized the latest Miocene beds represented by the Paraná and Camacho Formations exposed in northeastern Argentina and Uruguay.

As can be concluded from the data summarized above, the scutelliform species richness increased from three (two undescribed) species in the late Oligocene to five in the early Miocene and to six in the late Miocene. Fig. 4 shows that Monophoraster embraces the entire Miocene, discarding its importance as a precise biostratigraphic tool. However, occurrences of Iheringiella (late Oligocene-early Miocene), "Eoscutella" (early Miocene), and Abertella and Amplaster (middle Miocene-late Miocene), point to a more restricted interval, and prove to be slightly better biostratigraphically constrained. On the other hand, at the species level, the group as a whole turns out to be a useful temporal indicator, since there are taxa restricted to the late Oligocene ("Iheringiella"sp. A), to the early Miocene 
(Camachoaster maquedensis, "Eoscutella" mirandae, Monophoraster telfordi), to the middle Miocene (Abertella gualichensis, Abertella miskellyi) and to the late Miocene (M. duboisi, A. ellipticus, A. coloniensis).

When compared with the molluscan zones, the middle and late Miocene scutelliform genera Amplaster and Abertella correlate with the NVG Assemblage (middle Miocene) and the Aequipecten paranensis Zone (late Miocene). Camachoaster and "Eoscutella" are restricted to the early Miocene, with the early Miocene JR Assemblage (San Jorge Basin and Mazarredo Sub-basin) and the PA and RSP Assemblages (Austral Basin). Only one taxon seems to be restricted to the late Oligocene PP Assemblage ("Iheringiella" sp. A).

Ethical statement: authors declare that they all agree with this publication and made significant contributions; that there is no conflict of interest of any kind; and that we followed all pertinent ethical and legal procedures and requirements. All financial sources are fully and clearly stated in the acknowledgements section. A signed document has been filed in the journal archives.

\section{ACKNOWLEDGEMENTS}

M. Tanuz, Beatriz Aguirre-Urreta from the Universidad de Buenos Aires, M. Longobucco from the Museo Argentino de Ciencias Naturales and Alejandra Rojas (Facultad de Ciencias, UdelaR) assisted with material housed in the mentioned institutions, J. Cuitiño and L. Pérez kindly provided specimens for study, A. Kroh and $\mathrm{R}$. Mooi gave us permission to include their photos in the present paper, and A. Oleinik assisted us with the bibliography. The suggestions of the reviewers Andreas Kroh, Rich Mooi and James Nebelsick, were very useful for improving the manuscript.

\section{RESUMEN}

Diversidad y bioestratigrafía de las galletas de mar (Echinoidea: Scutelloida: Scutellifomes) del Oligoceno tardío-Mioceno tardío de Argentina y Uruguay

Introducción: Realizamos una síntesis actualizada de la composición taxonómica de las asociaciones de escutélidos del Oligoceno tardío-Mioceno tardío de Argentina y Uruguay. Objetivo: Ubicar los escutélidos en un marco estratigráfico refinado, a los efectos de observar su diversidad a lo largo del tiempo y la correlación de sus ensambles con los ya conocidos de moluscos. Métodos: Revisamos en detalle la procedencia geográfica y estratigráfica de los ejemplares y su asignación taxonómica, basándonos tanto en la bibliografía como en colecciones institucionales y producto de nuestras campañas de colecta. Resultados: El grupo está representado por 14 especies agrupadas en seis géneros, siendo identificadas en cuatro ensambles. Las edades numéricas recientemente obtenidas permitieron su ubicación en un esquema cronológico: "Iheringiella" sp. A se restringe al Oligoceno tardío, Camachoaster y "Eoscutella", y Monophoraster telfordi al Mioceno temprano, Abertella gualichensis y Abertella miskellyi al Mioceno medio, y Monophoraster duboisi, Amplaster coloniensis y Amplaster ellipticus al Mioceno tardío. Los escutélidos sin lúnula no están restringidos al Oligoceno tardío como se suponía. Monophoraster aparece en el Mioceno temprano y junto con Iheringiella abarcan largos períodos de tiempo, encontrándoselos entre los 25.3 Ma-18.1 Ma (Iheringiella patagonensis) y aproximadamente los $15 \mathrm{Ma}-6.48 \mathrm{Ma}$ (Monophoraster darwini). Se corrobora la presencia de Iheringiella en el Mioceno temprano del noreste de Patagonia, donde alcanza su punto más septentrional. Monophoraster darwini se encuentra desde el Mioceno medio hasta el Mioceno tardío (lapso para el cual previamente se consideraba restringido), ya que se trata de la especie presente en los bien conocidos "estratos con Monophoraster y Venericor". Conclusiones: Los escutélidos del PaleógenoNeógeno de Argentina y Uruguay se encuentran desde el Oligoceno tardío hasta el Mioceno tardío. Hay una buena correspondencia entre las edades numéricas, las biozonas de moluscos y los ensambles de escutélidos.

Palabras clave: Echinoidea; Scutelliformes; galletas de mar; Paleógeno; Neógeno; Argentina; Uruguay.

\section{REFERENCES}

Ameghino, F. (1898). Sinopsis Geológico-Paleontológica. Segundo Censo de la República Argentina. Tomo 1. 
Territorio. Buenos Aires, Argentina: Taller tipográfico de la Penitenciaría Nacional.

Ameghino, F. (1906). Les formations sedimentaires du Crétacé superieur et du Tertiare de Patagonie, avec un parallèle entre leur faunes mammologiques et celles de l'ancien continent. Anales del Museo Nacional de Historia Natural de Buenos Aires, 15(3), 1-568.

Bellosi, E. (1995). Paleobiogeografía y cambios ambientales de la Patagonia central durante el terciario medio. Boletín de Informaciones Petroleras, 44, 50-83.

Berg, A. (1898). Substitución de nombres genéricos. Comunicaciones del Museo Nacional de Buenos Aires, 1, 16.

Bernasconi, I. (1959). Equinoideos fósiles de la colección del Museo Argentino de Ciencias Naturales. Physis, 21(61), 137-176.

Camacho, H.H. 1974. Bioestratigrafía de las formaciones marinas del Eoceno y Oligoceno de la Patagonia. Anales de la Academia Nacional de Ciencias Exactas, Físicas y Naturales, 26, 39-57.

Chiesa, J.O., Parma, S.G., \& Camacho, H.H. (1995). Invertebrados marinos de la Formación El Chacay (Eoceno), Provincia de Santa Cruz, Argentina. Sistemática y bioestratigrafía. Monografías de la Academia Nacional de Ciencias Exactas, Físicas y Naturales, 11, 17-68.

Concheyro, G.A. (1988). Estudio bioestratigráfico de las sedimentitas del Terciario que aflora en las proximidades de Colonia Catriel. Provincia del Río Negro (Graduate thesis). Universidad de Buenos Aires, Argentina.

Cotteau, M.G. (1884). Échinides nouveaux ou peu connus. Bulletin de la Société Zoologique de France, 7, 1-185.

Cuitiño, J.I., \& Scasso, R.A. (2010). Sedimentología y paleoambientes del Patagoniano y su transición a la Formación Santa Cruz al sur del lago Argentino, Patagonia Austral. Revista de la Asociación Geológica Argentina, 66(3), 406-417.

Cuitiño, J I., Pimentel, M.M.,Ventura-Santos, R., \& Scasso, R.A. (2012). High resolution isotopic ages for the early Miocene "Patagoniense" transgression in Southwest Patagonia: Stratigraphic implications. Journal of South American Earth Sciences, 38, 110-122.

Cuitiño, J.I., Scasso, R.A., Ventura-Santos, R., \& Mancini, L.H. (2015a). Sr Ages for the Chenque Formation in the Comodoro Rivadavia region (Golfo San Jorge Basin, Argentina): Stratigraphic implications. Latin American Journal of Sedimentology and Basin Analysis, 22(1), 3-12.
Cuitiño, J.I., Ventura-Santos, R., Muruaga, P.J., \& Scasso, R.A. (2015b). Sr-stratigraphy and sedimentary evolution of early Miocene marine foreland deposits in the northern Austral (Magallanes) Basin, Argentina. Andean Geology, 42(3), 364-385.

Darwin, C. (1839). Journal and remarks. 1832-1836. The narrative of the surveying voyages of his Majesty's ships Adventure and Beagle between the years 1826 and 1836, describing their examination of the southern shores of South America, and the Beagle's circumnavigation of the globe, 3, 1-615.

Darwin, C. (1846). Geological observations on the volcanic Islands and parts of South America visited during the voyage of H.M.S. "Beagle". London: Appleton.

del Río, C.J. (1988). Bioestratigrafía y cronoestratigrafía de la Formación Puerto Madryn (Mioceno medio). Provincia del Chubut - Argentina. Anales de la Academia Nacional de Ciencias Exactas, Físicas y Naturales de Buenos Aires, 40, 231-254.

del Río, C.J. (2004). Tertiary marine molluscan Assemblages of Eastern Patagonia (Argentina): A biostratigraphic analysis. Journal of Paleontology, 78(6), 1097-1122.

del Río, C.J., Martínez, S.A., \& Scasso, R.A. (2001). Nature and origin of spectacular marine Miocene shell-beds of Northeastern Patagonia (Argentina): Paleoecological and bathymetric significance. Palaios, 16, 3-25.

del Río, C.J., Martínez, S.A., McArthur, J.M., Thirwall, M.F., \& Pérez, L. (2018). Dating late Miocene marine incursions across Argentina and Uruguay with Sr-isotope stratigraphy. Journal of South American Earth Sciences, 85, 312-324.

Desor, E. (1847). Sur quelques oursins fossiles de la Patagonie. Bulletin de la Société Géologique de France, 2(4), 287-288.

Durham, J.W. (1966). Clypeasteroids. In R.C. Moore (Ed.), Treatise on Invertebrate Paleontology. Pt. U(2). Echinodermata 3 (pp. 450-491). Lawrence: Geological Society of America and University of Kansas Press.

D’Orbigny, A.D. (1842). Voyage dans l'Amérique meridionale (le Brésil, la République Orientale de l' Uruguay, la République Argentine, la Patagonie, la République du Chile, la République de Bolivie, la République du Pérou), executé pendant les années 1826-1833. 3, Géologie, 4, Paléontologie. Paris: P. Bertrand.

Ihering, H. von. (1897). Os molluscos dos terrenos terciarios de Patagonia. Revista do Museu Paulista, 2, 217-382.

Ihering, H. von. (1900). The history of the Neotropical region. Science, 12, 857-864. 
Ihering, H. von. (1907). Les mollusques fossiles du Tertiaire et du Crétacé Supérieur de 1'Argentine. Anales del Museo Nacional de Buenos Aires, 3(7),1-611.

Ihering, H. von. (1927). Die Geschichte des Atlantischen Ozeans. Jena: Fischer.

Kroh, A., Mooi, R., del Río, C.J., \& Neumann, C. (2013) A new late Cenozoic species of Abertella (Echinoidea: Clypeasteroida) from Patagonia. Zootaxa, 3608, 369-378.

Lahille, F. (1898). Notes sur le nouveau genre de scutellides Iheringia. Revista del Museo de la Plata, 8, 439-451.

Lambert, J., \& Thiéry, P. (1921). Essai de nomenclature raisonneé des échinides, 5. Paris: Chaumont.

Loriol, P. de. (1901). Notes pour servir a l'étude des échinodermes. Bulletin de la Société Geologique de France, 2(9), 37-40.

Loriol, P. de. (1902). Notes pour servir à l'étude des échinoderms. Bulletin de la Société Geologique de France, 2(10), 1-52.

Martínez, S. (1984). Amplaster coloniensis n.g. n.sp. (Echinoidea, Monophorasteridae) del Mioceno de Uruguay. Memoria del III Congreso Latinoamericano de Paleontología, 3, 505-508.

Martínez, S. (1994). Bioestratigrafia (Invertebrados) de la Formación Camacho (Mioceno, Uruguay) (Doctoral thesis). Universidad de Buenos Aires, Argentina.

Martínez, S., Reichler, V., \& Mooi, R. (2005). A new species of Abertella (Echinoidea: Scutellina) from the Gran Bajo del Gualicho Formation (Late Early Miocene-Early Middle Miocene), Río Negro Province, Argentina. Journal of Paleontology, 79(6), 1229-1233.

Mooi, R., Martínez, S.A., \& Parma, S.G. (2000). Phylogenetic systematics of Tertiary Monophorasterid sand dollars (Clypeasteroida: Echinoidea) from South America. Journal of Paleontology, 74(2), 263-281.

Mooi, R., Martínez, S.A., \& del Río, C.J. (2016). A new South American Miocene species of 'one-holed' sand dollar (Echinoidea: Clypeasteroida: Monophorasteridae). Zootaxa, 4173(1), 45-54.

Mooi, R., Martínez, S.A., del Río, C.J., \& Ramos, M.I.F. (2018). Late Oligocene-Miocene non-lunulate sand dollars of South America: Revision of abertellid taxa and descriptions of two new families, two new genera, and a new species. Zootaxa, 4369(3), 301-326.
Mortensen, T. (1948). A monograph of the Echinoidea. IV, 2. Clypeastroida. Copenhagen: C.A. Reitzel.

Ortmann, A. (1902). Tertiary Invertebrates. Reports of the Princeton University Expedition to Patagonia, 4(2), 45-332.

Palazzesi, L., Barreda, V.D, Cuitiño, J.I., Guler, M.V., Tellería, M.C., \& Ventura-Santos, R. (2014). Fossil pollen records indicate that Patagonian desertification was not solely a consequence of Andean uplift. Nature Comunications, 5, 1-8.

Parma, S.G. (1985). Eoscutella Grant y Hertlein (Echinodermata: Clypeasteroida) en el Patagoniano (Terciario inferior) de la Provincia de Santa Cruz, República Argentina. Ameghiniana, 22(1-2), 35-41.

Parras, A., \& Casadío, S. (2005). Taphonomy and sequence stratigraphic significance of oyster-dominated concentrations from the San Julián Formation, Oligocene of Patagonia, Argentina. Palaeogeography, Palaeoclimatology, Palaeoecology, 217(1-2), 47- 66.

Parras, A., \& Griffin, M. (2009). Darwin's Great Patagonian Tertiary Formation at the mouth of the Río Santa Cruz: a reappraisal. Revista de la Asociación Geológica Argentina, 64(1), 70-82.

Parras, A., Dix, G.R., \& Griffin, M. (2012). Sr-isotope chronostratigraphy of Paleogene-Neogene marine deposits: Austral Basin, southern Patagonia (Argentina). Journal of South American Earth Sciences, 37, 122-135.

Pérez, L.M., Martínez, S., \& Parma, S.G. (2011). Abertella Durham, 1955 (Echinoidea: Scutellina) en la Formación Paraná (Mioceno Tardío). Reunión Anual de Comunicaciones de la Asociación Paleontológica Argentina (Luján, 2011), Resúmenes, 46-47.

Rossi de García, E., \& Levy, R. (1989). Presencia de Amplaster n. sp. (Echinodermata, Clypeasteroida) en el Terciario de Patagonia. 4 Congreso Argentino de Paleontología y Bioestratigrafia, Actas, 4, 89-92.

Teisseire, A. (1928). Contribución al estudio de la geología y paleontología de la República Oriental del Uruguay. Región de Colonia. Anales de la Universidad, 37(122), 319-469.

Uliana, M.A., \& Camacho, H.H. (1975). Estratigrafía y Paleontología de la Formación Vaca Mahuida (Provincia de Río negro). Actas 1 Congreso Argentino de Paleontología y Bioestratigrafía, Tucumán, 2, 357-373.

See Digital Appendix at: / Ver Apéndice digital en: revistas.ucr.ac.cr 